\title{
解説記事
}

\section{地域の将来像を人口から考える 一社人研『地域別将来推計人口』の結果から一}

Population Projection and Its Implications: The Future Image of Municipalities in Japan

\author{
江崎 雄治・西岡 八郎・鈴木 透・小池 司朗・ \\ 山内 昌和・菅 桂太・貴志 匡博 \\ ESAKI Yuji, NISHIOKA Hachiro, SUZUKI Toru, KOIKE Shiro, \\ YAMAUCHI Masakazu, SUGA Keita, and KISHI Masahiro
}

（2013年11月 20 日受付 2014 年 1 月 18 日受理）

\begin{abstract}
本稿は, 国立社会保障 -人口問題研究所の『日本の地域別将来推計人口 (平成 25 年 3 月推計)』の手法と結果に ついて解説するものである。まずコーホート要因法による将来人口推計は，コーホートの安定的な経年変化を将来 に延長することをその手法の基礎に置いていることから，少なくとも近い将来に関する限り，かなり高い精度を有 することを説明する．2025年までの推計結果については，特に非大都市圈の人口減少の加速とともに，大都市圈 郊外地域における急激な高齢化について指摘している. さらに大都市圈では, その後の死亡数の増加により, 2040 年までの期間に非大都市圈の後を追う形で人口減少局面に入る.
\end{abstract}

This paper briefly introduces the method and results of Regional Population Projections for Japan: 2010-2040 published in March 2013 by the National Institute of Population and Social Security Research. We demonstrate that a population projection using the cohort component method maintains reasonably high accuracy, at least for the near future. For the results of the projection by 2025, population declines in municipalities in nonmetropolitan areas will accelerate, and rapid population aging in the suburbs around metropolitan areas will be unavoidable. We emphasize that because deaths will increase in metropolitan areas after population aging, populations in metropolitan areas will decline following the declines in nonmetropolitan areas.

キーワード：将来人口推計, 市区町村, コーホート, 高齢化, 人口減少

Key words: population projection, municipality, cohort, aging, population decline

\section{I はじめに}

地域の変容は地理学における根源的な関心の一つで あるが, その変容の指標として，あるいはまた変容を もたらす要因として, 人口変化は最も重要なものであ ろう.

また，実務の世界にあっても，地域の人口に関する 情報は欠かすことのできないものであり，特に将来の 人口変化は，多くの実務家にとって非常に大きな関心 事となっている，たとえば民間企業であれば，出店計 画などマーケティングの基礎的資料であるし，自治体 であれば，年齢別人口の増減に大きく左右される福祉 関係などの予算を中心に，財政見通しの根拠となる。

そのため, 各企業や自治体は独自に将来人口の推計 を行うことがある。また日本では, 厚生労働省の一機
関である国立社会保障・人口問題研究所（以下社人研 と略す）が 5 年おきに都道府県別・市区町村別の推計 を行い, 結果を公表しており, こちらも広く利用され ている（西岡ほか $2007 a, b ）$.

2013 年 3 月, 最新の推計結果である『日本の地域別 将来推計人口 (平成 25 年 3 月推計)』が公表された. 著者のうち, 社人研在籍の鈴木, 小池, 山内, 菅, 貴 志が実際の推計業務を担当し, 西岡, 江崎の2名の元 担当者が所外委員として助言にあたった．本稿ではこ の推計結果を方法論やその精度とともに解説し, 今後 の地域の変容を考える上で基礎となる知見を提示して いきたい.

なお，この社人研による地域別の将来人口推計につ いては，これまで多くの地理学出身者が業務を担って おり, 今回は小池, 山内, 貴志, 江崎の 4 名の地理学 
出身者がプロジェクトの構成員となっている.

本稿では紙幅の関係で推計結果の紹介については最 小限にとどめる，詳細については，社人研ホームペー ジから全市区町村の年齢別の推計結果も含めて, 多く の情報を入手することができる．また，推計手法の詳 細（仮定值の設定方法など）も含めた報告書が刊行さ れている（国立社会保障・人口問題研究所 2013).

なお本稿は, 著者各人の研究者としての見解をまと めたものであり, 社人研の公式見解ではないことに留 意されたい.

\section{II 将来人口推計の方法と精度}

1. コーホート要因法とその信頼性

一般に社会経済の諸指標について将来の変化を見通 すことは困難であり, 将来人口の推計についても, 同 様の印象をもつ向きは少なくないと思われる。つま り, 将来人口推計がどの程度の精度を有するのか, ま ずはその点に関心が持たれるであろう。

本章では，世界的に広く用いられ，社人研の推計に も使われている手法, すなわちコーホート要因法につ いて簡単に解説し, その原理から, 少なくとも近い将 来に関する限りは高い精度を有することを示したい. なおコーホート要因法や地域別の将来人口推計の方法 論についての詳細は, 山口(1990), 濱・山口(1997)を 参照されたい.

コーホートとは, 通常同時出生集団と訳されてお り，ある一定の期間（1年あるいは 5 年をとる場合が 多い)に生まれた集団を指す。一般には世代という言 葉と置き換えてもさほど問題はない. ある年に多く生 まれた世代は年齢を重ねても多いまま推移し, 少なく 生まれた世代は少ないまま推移する。第 1 次べビー ブーム世代（団塊の世代）がいまだに大きな規模を維 持していることからも，これは容易に理解されるだろ j.

コーホート要因法は，このようにコーホートが加齢 とともにその規模を保ちつつ推移するという点を, そ の方法論の基礎に置いており，それゆえに一定の精度 が保障されていると言うことができる.

例として，2014年において 2015 年の 47 歳の人口を 推計する場合を考える. 2014年の46歳と大差ない数
值であろうことは，直感的にも理解できるであろう. むろん同值ということはなく，一年間に死亡する分減 少し, 地域外との転出入で増減する。言うまでもなく 当該年齢での死亡数や転出入の人数は経年的に変化す るが, これまでのデータの蓄積から傾向はよく把握さ れており，合理的な仮定值を置くことは十分可能であ る．またそもそも，低年齢層では死亡が少なく，中高 年層では転出入が少ない，そのため多くの年齢層でこ れらの予測が容易である点も，高い推計精度の実現を もたらしている.

ここでは 2015 年の 47 歳の推計方法を例にとったが, 言うまでもなく，他の年齢層も，1歳以上については 同様に推計できる。 あとは出生についての仮定から 0 歳人口を推計すれば，それらの合計によって 2015 年 の総人口が求められる。そして2016年以降について も, 順次同様に求めることができる.

なお，以上は各年各歳での推計であるが，市町村別 などの地域人口推計の場合は，必要となるデータの入 手可能性などの関係から，5歳階級人口を 5 年ごとに 推計する場合が多い.もちろん，同様の考え方によっ て, 近い将来の人口については比較的高い精度で推計 可能である. 社人研の『地域別将来推計人口』も，5 歳階級人口の 5 年ごとの推計となっている.

このように安定性, 信頼性の高いコーホート要因法 は，諸外国においても公的な将来人口推計に用いられ ている．米国ではセンサス局により州ごとの将来人口 推計が行われているほか(United States Census Bureau 1996, 2005), 各州においては郡や市ごとの推計も行わ れている。 またEUでは, 域内で統一的に用いられて いる3 階層の地域区分のうち，中位の階層(NUTS 2) を単位として，やはりコーホート要因法による将来人 口推計が行われている(Giannakouris 2010).

2. 出生数. 死亡数の変化の安定性

上述のように，0歳の将来人口については，出生に ついての仮定を置くことで求めることになる．日本の 合計出生率（合計特殊出生率）を見ると，今世紀に 入ってからの変動は比較的小さく（2001年 $1.33 \rightarrow 2005$ 年 $1.26 （ 1947 \sim 2012$ 年における最低) $\rightarrow 2012$ 年 1.41)，長期的に人口を維持することができ る水準 (人口置換水準) の 2.07 をなり下回った状態 


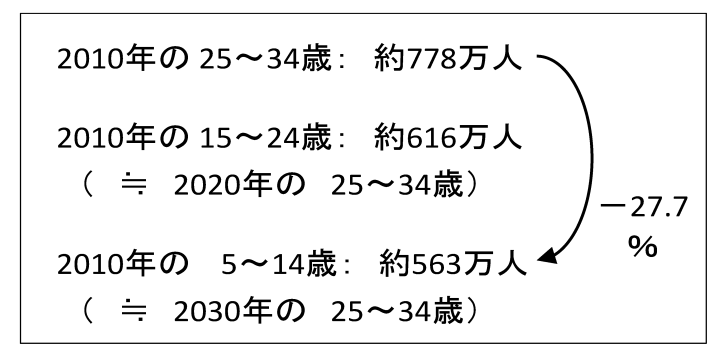

図 1 今後の日本における母親世代人口の見通し 資料：国勢調査より作成.

で推移している.

ただし合計出生率は，第1次ベビーブーム後の急減 （1947年4.54（1947～2012年に打ける最高） $\rightarrow 1950$ 年3.65 $\rightarrow 1955$ 年 2.37$)$ などに見られるように, 比較 的短期間で大きく変化することもある，外国では，た とえばスウェーデンにおいては，育児支援策の充実と その後の予算縮小等や景気変動の影響下にあって, 比 較的短期間に変動が見られた（1983年 $1.61 \rightarrow 1990$ 年 $2.14 \rightarrow 1999$ 年 $1.51 \rightarrow 2010$ 年 1.98$)$.

このため, 日本に打いても今後の政策次第で出生率 が上昇することも十分考元られる゙，それでも出生数 （言うまでもなく，将来の人口変化に直接影響するの は, 出生率ではなく, 出生数である) の今後について は，減少基調となることがほほ確実である。

これは前項で述べたコーホート変化の安定性（規模 の大きい世代は大きいまま推移し，小さい世代は小さ いまま推移する）功説明できる. 出生数は, 端的に 言って母親世代の人口規模と出生率の積によって決ま るが，このうち母親世代の人口規模は数十年先までほ ぼ確定している。これを示したものが図1である。 日 本では 2010 年の 25 ～34歳の女子人口は約 778 万人で あった. $15 〜 24$ 歳女子人口は約 616 万人であり, む万 ん以後 10 年間, 若干の死亡による減少と海外との間の 転出入があるが，この数を大きく変化させるものでは ない.つまり 2020 年において母親世代の中核をなす 25 〜 34歳女子人口は, ほぼ 600 万人強と見積もられ， 2010年と比べて2割ほど減少する。したがって今後若 干の出生率の上昇があったとしても，それは打ち消さ れ, 出生数の増加は容易にはもたらされない. 同様 に, 2030 年の $25 \sim 34$ 歳女子人口は 500 万人台の半ばで あろう。これは2010年から見て 3 割近くの減少とな り, 今後の出生数の回復がいかに難しいかが分かる.
一方で死亡数についても同様のことが言える．死亡 数は年齢別人口にその年齢での死亡確率を乗じること で求められる，死亡確率は，まず，子どもや若年層に ついては極小の值となることは言うまでもなく，現在 の日本では40歳代，50歳代に扔いてもかなり小さい 值となっている. 高齢層においては年齢とともに徐々 に值が上昇するが，これについても先に見た出生率に 比べれば，経年変化はかなり安定している，したがっ て死亡数についても，その変化は，年齢別人口の変化 に相当程度規定されると言ってよい. 日本では現在, 20 世紀前半の多産少死局面に生まれたコーホートが 後期高齢期に入ってきており, 死亡数が増加してい る. そして第 1 次ベビーブーム世代の多くが平均寿命 に差しかかる数十年後にかけて, 死亡数は増え続ける ことになる。

図2 に日本全国における出生数と死亡数の推計值を 掲げる. 出生数については出生率の仮定の違い（高 位・中位・低位）による幅があるが，いずれにしても 減少が継続する，死亡についても同様に3種の仮定が あるが，差が比較的小さいためここでは中位のみ示し た．2030年代にかけて増加が続くことが分かる．こ のように出生数が減少し, 死亡数が増加してその差が 拡大を続けることで, 日本の人口は着実に，その速度 を上げながら，減少するのである.

\section{3. 多様な転出入状況への対応}

以上見てきたような出生および死亡の変化の安定性 は，抒扔むね日本全国で一様であると考えてよい。つ まり, 日本の各市区町村は, その年齢構造の違いによ りタイムラグはあるものの, 出生数と死亡数の差, す なわち自然増加数が正から負の值へ，そして減少幅の 拡大へという流れを共有している。したがって，社人 研の『地域別将来推計人口』において各市区町村の推 計值の差をもたらすのは, 主として転出入人口という ことになる.これについては出生数や死亡数に比べ, 経年変化が大きく, 特に小規模の自治体では変化パ ターンの把握が難しい．このため社人研では年齢別の 転出入状況（具体的には純移動率）の仮定に特に神経 を使っている.

今回の『地域別将来推計人口（平成 25 年 3 月推計)」 の場合, まず, 純移動率が安定している多くの市区町 


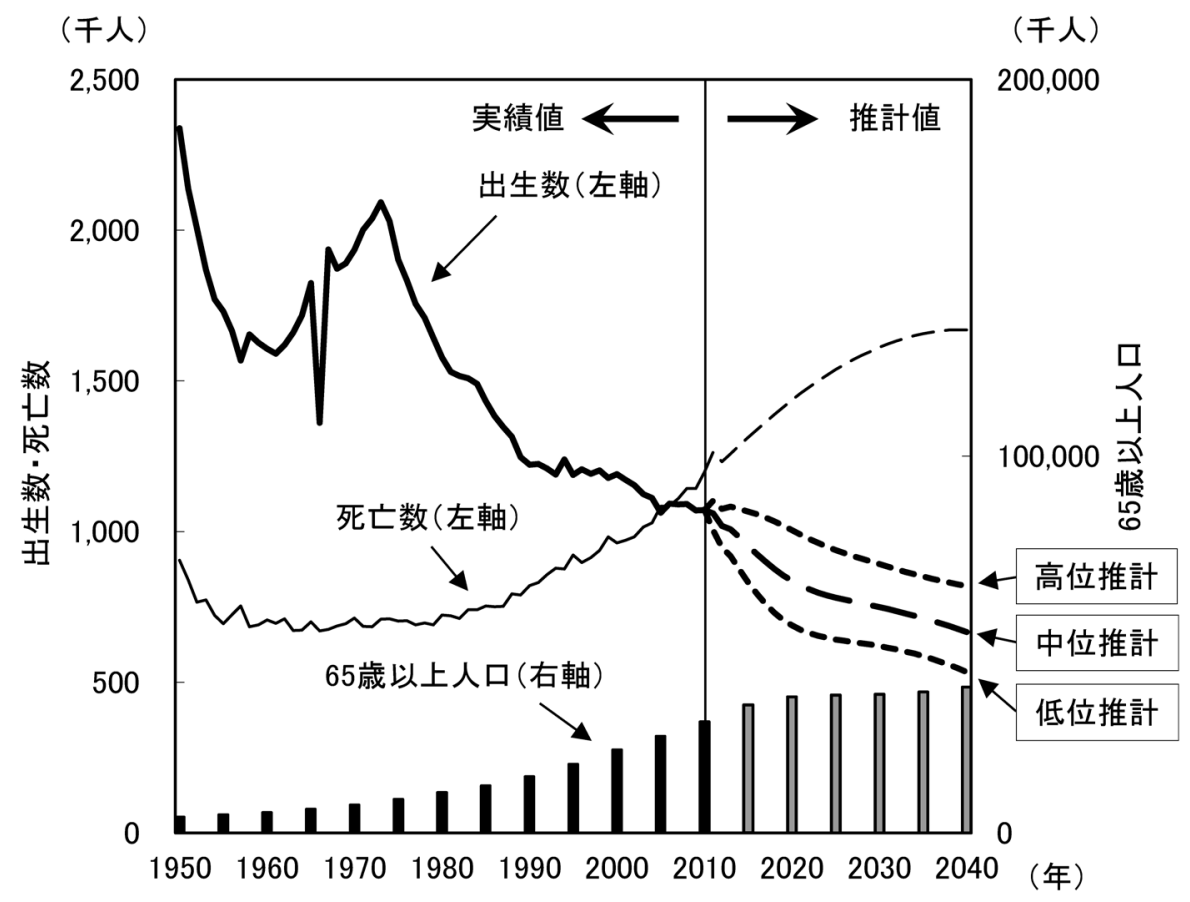

図2 日本の出生数, 死亡数および 65 歳以上人口の変化と推計值 注：合計出生率の仮定 高位推計： 1.60 中位推計：1.35 低位推計： 1.12 資料：国勢調査，人口動態統計，『日本の将来推計人口 (平成 24 年 1 月推計)』 （国立社会保障・人口問題研究所）より作成.

村では，直近の実績值すなわち2005～2010年の純移 動率を，近年の全国的な移動の鎮静化を反映して，一 律に縮小させる形で仮定值としている．小規模な自治 体を中心に，経年変化が安定しない自治体について は, より長い期間の純移動率の観察から変化を見通す など，さまざまな工夫を凝らしている，さらに今回の 推計では，東日本大震災の影響も考慮しなくてはなら ない。これについては，2010年までの変化だけでは なく，住民基本台帳人口移動報告等で震災を挟んだ期 間の変化を見ることで, 震災後の避難と帰還を織り込 んだ推計值を得るべく努めている.

これらの結果，今回の『地域別将来推計人口』で は, 計 16 種類の純移動率仮定值算出方法を用意し, 全国の市区町村の状況に応じてそれらを個別に適用す るという，かつてない手の达んだ方法を採ることと なった（詳細については国立社会保障・人口問題研究 所(2013)を参照されたい).

このように，その扱いが難しい純移動率ではある が，以前に比べれば推計結果に及ぼす影響は小さくな りつつある。この理由も先述の出生や死亡と同様,
コーホートの考え方で説明できる。それは，近年の出 生数の減少から，移動の主役である若年人口の数十年 先までの減少を見通せるためである。つまり近年で は，人口の変化に対する寄与を見た場合に，相対的に 自然増加（減少）の寄与が社会増加（減少）よりも大 きくなっており，このことも，『地域別将来推計人口』 の精度向上につながっていると言うことができる.

4. 推計結果の精度一『平成 15 年 12 月推計』と実 績值の比較一

ここでは社人研による『平成 15 年 12 月推計』と実 績值を比較することで，推計の適合状況を検証する. 『平成 15 年 12 月推計』は 2000 年の国勢調査人口を ベースに，2005年以降の市区町村人口を 5 年ごとに推 計していることから，2005年と 2010 年の 2 時点につ いて実績值，すなわち国勢調査人口との比較が可能で ある。ここでは, 社人研による推計人口を，2010年 の国勢調查時点における市区町村境域に組み替えたも のを用意し，国勢調査人口と比較する。2005年時点 の国勢調査人口も，同様に2010年の境域で組み替え 
E-journal GEO 2013 Vol. 8(2)

表 1 『市区町村推計 (平成 15 年 12 月推計)』の䛊差率

\begin{tabular}{|c|c|c|c|c|}
\hline \multirow{2}{*}{ 推計誤差率 } & \multicolumn{2}{|c|}{2005 年実績值との比較 } & \multicolumn{2}{|c|}{2010 年実績値との比較 } \\
\hline & 市区町村数 & 割合（\%） & 市区町村数 & 割合（\%） \\
\hline$-10 \%$ 未満 & 4 & 0.2 & 46 & 2.6 \\
\hline$-10 \%$ 以上 $-5 \%$ 未満 & 50 & 2.9 & 274 & 15.7 \\
\hline$-5 \%$ 以上 $-3 \%$ 未満 & 153 & 8.8 & 301 & 17.2 \\
\hline$-3 \%$ 以上 $-1 \%$ 未満 & 517 & 29.6 & 376 & 21.5 \\
\hline - $1 \%$ 以上 $1 \%$ 未満 & 649 & 37.1 & 315 & 18.0 \\
\hline $1 \%$ 以上 $3 \%$ 未満 & 248 & 14.2 & 193 & 11.0 \\
\hline $3 \%$ 以上 $5 \%$ 未満 & 62 & 3.5 & 107 & 6.1 \\
\hline $5 \%$ 以上 $10 \%$ 未満 & 52 & 3.0 & 84 & 4.8 \\
\hline $10 \%$ 以上 & 12 & 0.7 & 51 & 2.9 \\
\hline 合計 & 1,747 & 100.0 & 1,747 & 100.0 \\
\hline
\end{tabular}

資料：『日本の市区町村別将来推計人口（平成 15 年 12 月推計)』(国立社会保障 - 人口問題研究所), 国勢調査より作成.

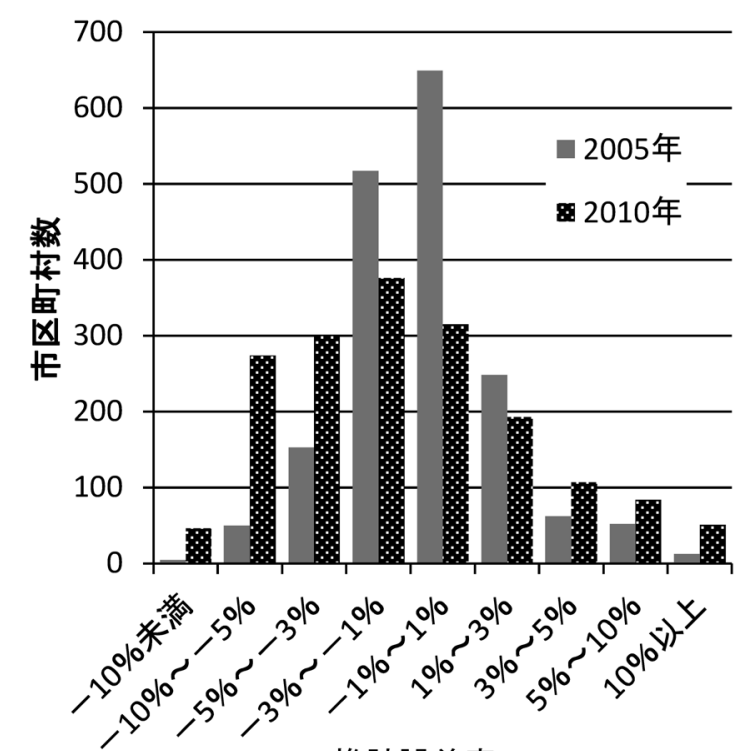

推計誤差率

図3『市区町村推計 (平成 15 年 12 月推計)』の誤差率 資料：『日本の市区町村別将来推計人口（平成 15 年 12 月推計)』(国立社会保障 - 人口問題研究所), 国勢調 査より作成.

て用いる。2010年国勢調査時点の全国1,750市区町村 のうち, 推計当時噴火災害による全島避難で推計人口 の算出ができなかった東京都三宅村と, 山梨県旧上 九一色村の分村合併により推計人口の組み替えが難し い甲府市，富士河口湖町を除く 1,747 市区町村を対象 とした。

その各市区町村について, 推計誤差率を, （実績値 -推計值) /推計值によって求めた（表1，図3）。 ま ず， 5 年後の 2005 年時点について見ると，「-1\%以上 $1 \%$ 未満」が3分の 1 強を占め, 両隣の「-3\%以上$1 \%$ 未満」「 $1 \%$ 以上 $3 \%$ 未満」を合わせると 8 割を超え
る市区町村数となるなど, 全体としてきわめて高い推 計精度となっていることが分かる. 10年経過後の 2010 年時点では,「-1\%以上 $1 \%$ 未満」は 2 割弱に, $\lceil-3 \%$ 以上 $-1 \%$ 未満」「 $1 \%$ 以上 $3 \%$ 未満」を合わせ ても 5 割強まで低下するが,「- $5 \%$ 以上 $-3 \%$ 未満」 $\lceil 3 \%$ 以上 $5 \%$ 未満」をも含めれば約 4 分の 3 であり， 引き続き相当程度の推計精度を維持している.

一方で誤差率「-10\%未満」および「 $10 \%$ 以上」も わずかながら存在する。これらは比較的小規模な市区 町村であり，後者の過小推計については，例えば三重 県朝日町（2010年の誤差率 $49.9 \%)$ ，埼玉県滑川町 （同 $35.2 \%$ ）など，大都市圈郊外の面積の小さい自治 体で, 宅地開発が進行中，といった特徵を有する場合 が多い.こういったタイプの小規模な自治体では元 来, 短期間での人口増加率の振れ幅がかなり大きくな ることは避けられず，そもそも将来人口推計は困難で ある，前述のように，社人研においてはできる限りこ ういった転入状況の変化も織り込んだ仮定值の設定を 行うよう努めてはいるが，なお限界があることは否め ない，当該夕イプの自治体については，宅地開発の計 画等も考慮に入れつつ，ある種のシナリオを設定する ことから純移動率を仮定し，推計を行うことが一つの 方法だが，宅地開発の現況や予定といった詳細な地元 情報を国の機関である社人研が一元的に把握し続ける ことは不可能である. したがって当該タイプの自治体 に限らず，転出入状況について特有の変化を観察しつ つある自治体では, 独自に将来人口推計を行うことも 選択肢の一つであろう. 


\section{III 最新の『地域別将来推計人口』から見た地域 の将来像}

\section{1. 推計の概要}

社人研の『地域別将来推計人口（平成 25 年 3 月推 計)』は, 2010年の国勢調査人口を基準人口として用 い, 2040 年までの将来人口を 5 年ごとに推計してい る. 仮定值設定のために観察するデー夕は基本的に 2010 年までのものであるが，先述のように，東日本 大震災の影響を織り込むため, 2012 年までの住民基 本台帳人口移動報告等も利用している.

これまでは都道府県別の推計と市区町村別の推計を 個別に行っていたが，今回は市区町村別の推計結果を 県ごとに合算することで，両方の推計值を同時に公表 した. ただし, 福島県については福島第一原子力発電 所の事故があり, 周辺の市町村については今後の居住 状況の見通しを立てることが困難なことから，市町村 別の推計は行わず，福島県を単位とした推計を行って いる.

\section{2. 地方圈の高齢化と人口減少}

福島県を除く各県の1,683市区町村（776市，715 町，169村，および東京都の23区）における，推計に 基づく 2010 ～ 25 年および2010 2040年の人口変化 率について，地域ブロック別に市区町村数の構成を見 たものが表 2 および図 4 である。図4から，2010～25 年においては「-20\%以上 $0 \%$ 未満」，つまり 2025 年 にかけて総人口が $20 \%$ までの減少となる市区町村が 大勢を占めることが分かる。ただし，北海道と四国で は, 「 $-40 \%$ 以上 $-20 \%$ 未満」も同程度の構成比と なっている。一方で関東では「 $\Gamma \%$ 以上」の構成比が 2割近くとなっており, 今後しばらくは人口増加とな る自治体も少なくない。 また，中部や九州・沖縄も， 関東に次いで人口増加が見込まれる自治体が多い.

さらに2010〜 40年の変化を見ると，「- $40 \%$ 未満」 の市区町村数が大幅に増加する。 とくに北海道と四国 では半数近くの自治体がこのカテゴリーに入ることと なる．関東においても増加となる自治体はかなり少な くなり,「 $-40 \%$ 以上 $-20 \%$ 未満」の構成比が最も大 きくなる。そして全国1,683市区町村の合計では，2 割強の自治体で「- $40 \%$ 未満」という大幅な人口減少
となり，さらに「- $40 \%$ 以上 $-20 \%$ 未満」も合わせれ ば，実に約 7割を占めることになる。

また多くの自治体において高齢化も一段と進行する （図 5)．全国1,683市区町村のうち，2010年の時点で は，老年人口割合（65歳以上人口の割合）が $40 \%$ 以 上となっている自治体の割合は $5.2 \%$ にしか過ぎない が，2025年にはこれが $32.1 \%$ へ急上昇する．さらに 老年人口割合 $50 \%$ 以上の自治体も，2010年のわずか $0.5 \%$ から, 2025 年には $4.8 \%$ と一定の割合を占めるよ うになる，特に中国，四国では，それぞれ $10.3 \%$, $15.8 \%$ と，いわゆる「限界自治体」（65歳以上人口が 半数を超え，財政の維持などが困難になりつつある自 治体）がかなりの存在感を持つことになるだろう.

言うまでもなく，このような高齢化と人口減少は表 裏一体の関係にある。ここでは, 山形県において, 2025 年の老年人口割合が最も高い $46.1 \%$ となると予測 される西川町と，それに続く $45.3 \%$ が見込まれる朝日 町を例に説明する. 図6に両町の 2010 年と, 推計から 得られた 2025 年の人口ピラミッドを掲げる。まず 2010年において，女性は「逆ピラミッド」に近い形 状となるなど，両町とも厚い高齢層を擁しており，し たがって毎年の死亡数はすでにかなり高い水準にあ る。そして，両町とも第1次べビーブーム世代を含む $60 \sim 64$ 歳とその一つ下の年齢階級が, 高齢層と同様 あるいはそれ以上に厚い。一方でそれより若い年齢層 はかなり少なくなっていることから，層の厚い55〜 64 歳が高齢者となる今後しばらくは，必然的に老年 人口割合が大きく上昇する。同時にその年齢層からも 今後多くの死亡数が発生するため, 着実に人口減少が 進む.

もちろん，若年層の町外への転出も織り込まれてお り, 図6からも分かるように青壮年層の縮小も進む が，すでに青壮年層は総人口に占める割合がかなり小 さくなっているために，人口減少に及ぼす影響はさほ ど大きくはない.つまりこのような過疎地域における 人口減少の主たる要因は, かつてのような若年層の流 出ではなく，相対的に層の厚くなった高齢層の死亡な のである

このような自治体の中山間地などには，主に高齢者 からなる，いわゆる限界集落が多く存在する。一部に は，新たな居住者を得て持続可能性を獲得していく集 


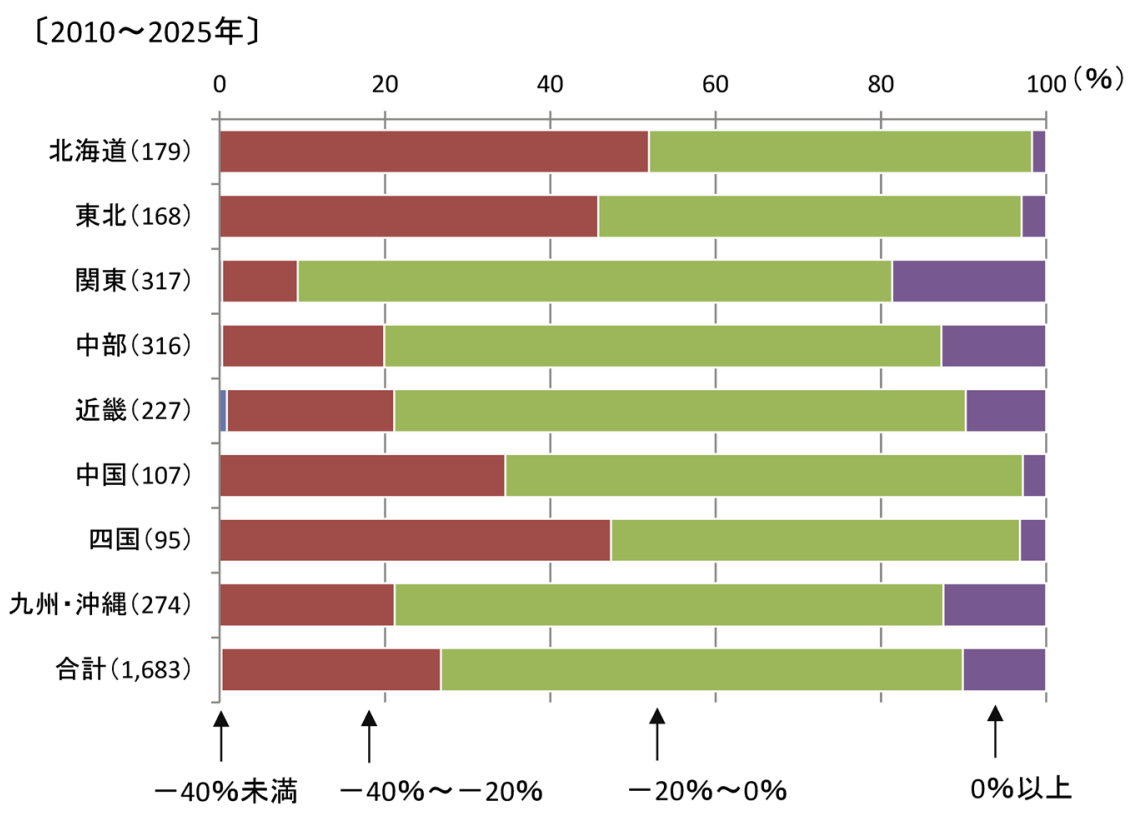

[2010 2040年]

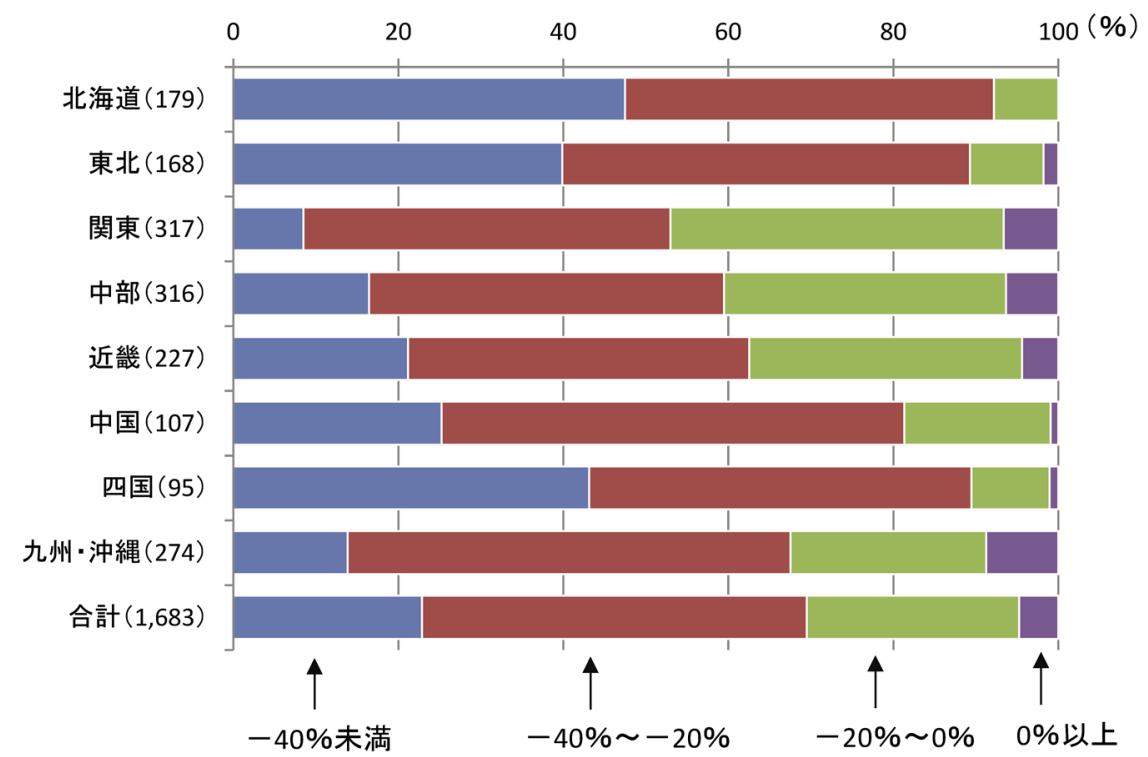

図 4 『地域別将来推計人口（平成 25 年 3 月推計）』に基づく今後の人口増加率別にみた市区町村の割合 注：（）内は当該地域内の市区町村数を表す。地域区分は以下の通り。

北海道：北海道東北：青森県, 岩手県, 宮城県, 秋田県, 山形県

関東：茨城県，栃木県，群馬県，埼玉県，千葉県，東京都，神奈川県

中部：新潟県, 富山県, 石川県, 福井県, 山梨県, 長野県, 岐皁県, 静岡県, 愛知県

近畿：三重県, 滋賀県, 京都府, 大阪府, 兵庫県, 奈良県, 和歌山県

中国：鳥取県, 島根県, 岡山県, 広島県, 山口県 四国：徳島県, 香川県, 愛媛県, 高知県

九州・沖縄：福岡県, 佐賀県, 長崎県, 熊本県, 大分県, 宮崎県, 鹿児島県, 沖縄県

資料：『日本の地域別将来推計人口（平成 25 年 3 月推計)』(国立社会保障・人口問題研究所）より作成.

落もあるとは思われるが，今後日本全体で若年層が縮 小していく中で，またその限られた若年層が大都市へ 集中する傾向が未だ観察される中で，すべての集落が 十分な数の来住者を迎え, 存続していけるとは考えら
れない，先に見たような各自治体における15年間で の $20 \sim 40 \%$ の人口減少，あるいは $40 \%$ を超える減少 というのは，ミクロに見ればこういった集落が徐々に 消滅に向かう過程とも言えるのである. 

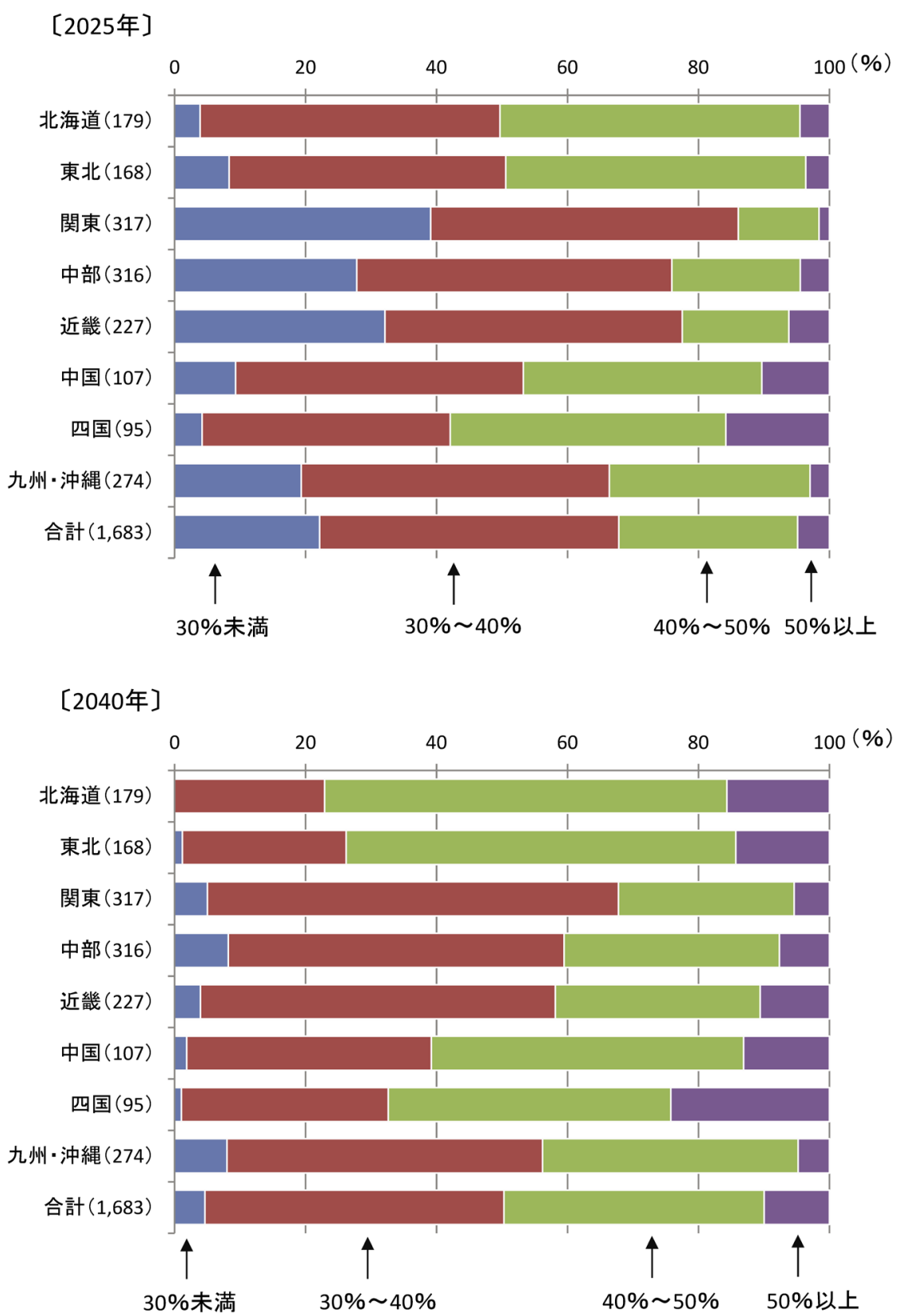

図 5 『地域別将来推計人口（平成 25 年 3 月推計）』に基づく今後の老年人口割合別にみた市区町村の割合 注：（）内は当該地域内の市区町村数を表す．地域区分は図 4 と同じ.

資料：『日本の地域別将来推計人口（平成 25 年 3 月推計)』(国立社会保障 ・人口問題研究所）より作成.

3. 大都市圈郊外の急激な高齢化

『地域別将来推計人口 (平成 25 年 3 月推計)』の結果 のもう一つ重要なポイントは, 今後高齢化の最前線は 大都市圈に移るということである.とりわけ大都市圈 郊外に位置する自治体では，高齢人口のかつてないほ どの急激な増加が避けられない.

これは，高度経済成長期に大都市圈に流入した世代 の高齢化が本格化するためである。よく引き合いに出
されるのが, 高度経済成長期にちょうど就職, 進学の 年齢に達した第 1 次ベビーブーム世代であるが，もち ろんその前後（とくに前）の世代も含まれる．第二次 世界大戦前から戦争直後までの多産少死局面に生まれ た世代とまとめることができよう。彼らは，高度経済 成長期に就職, 進学のため大都市圈（主として都心 部）に転入後，1970年代～1980年代に結婚・子ども の誕生といった世帯拡大期を迎え, 当時開発が進めら 
〔西川町 2010年]

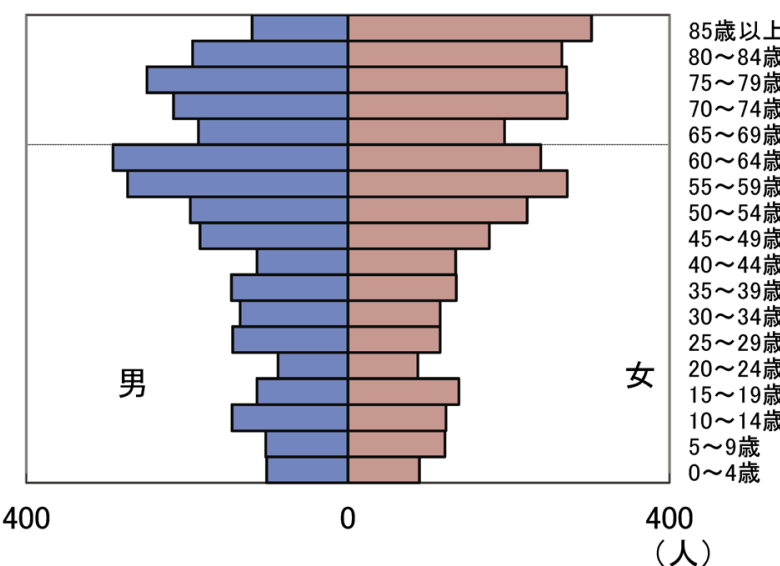

[朝日町 2010年]

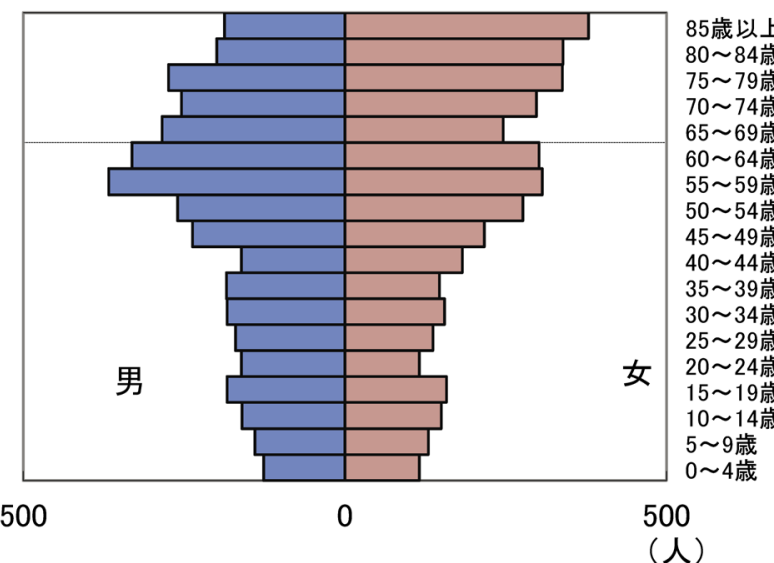

[西川町 2025年(推計)]

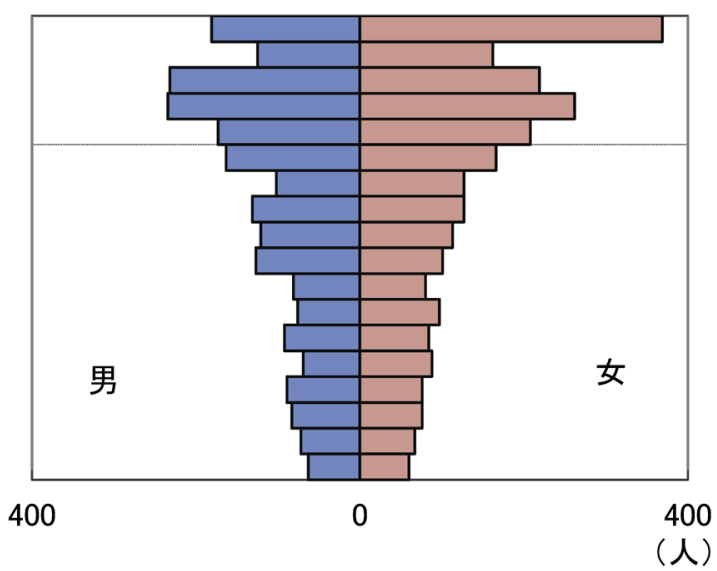

[朝日町 2025年(推計)]

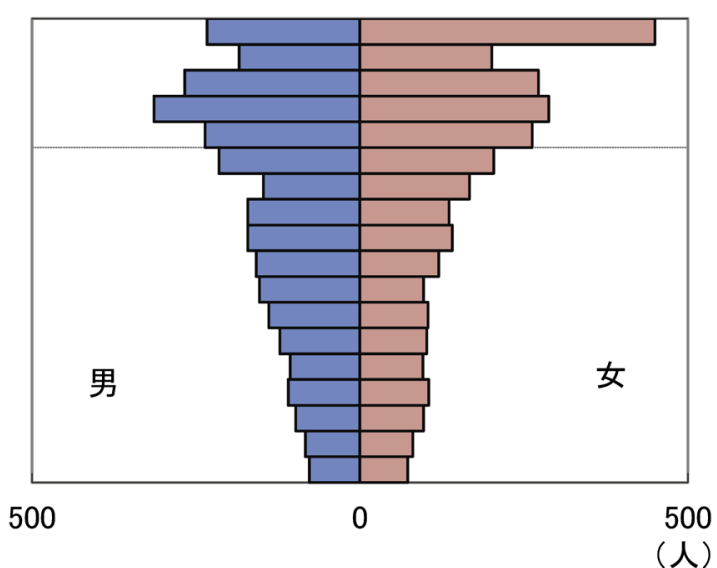

図6 山形県西川町・朝日町における今後の年齢別人口の変化

資料：国勢調査, 『日本の地域別将来推計人口（平成 25 年 3 月推計)』

（国立社会保障・人口問題研究所）より作成.

れたニュータウンなど，郊外の新興住宅地に続々と居 を構えた。このような新興住宅地は，その多くがもと もとは人口が希薄であった丘陵地などに建設されたこ とから，そういった開発がなされた自治体では，彼ら の世代と比べると，その上の世代の層が相対的にかな り薄い. その比の大きさはその後も維持され，現在に 至っている．つまり郊外の自治体では，これまで高齢 者が少なかった一方で，いわば「高齢者予備軍」が大 量に存在してきた。したがって彼らが高齢期に突入す ることで, 高齢者人口が急増するのである.

現在彼らの多くは65歳に達しつつあることから, 今後はさらに後期高齢者（75歳以上）の急増が焦点 となる。表2は, 1,683市区町村の推計結果から, 2010 ～ 25 年に後期高齢者が何倍に増加するかを求め,
その上位 50 位までを示したものである。この上位 50 位までは，すべて 15 年間で 2 倍以上という急激な増加 となることが分かる．第 1 位の埼玉県三郷市，第2位 の同鶴ヶ島市を筆頭に，ほとんどすべてが三大都市圈 郊外の市または町である。 また,この表には千葉市や 相模原市といった政令指定都市も含まれるが，人口規 模が大きい分, 実数の増加も大きい. 千葉市では 2010 年の約 8 万 1000 人が 2025 年には約 18 万 4000 人 に，同様に相模原市では約 5 万 4000 人が約 12 万人へ と増加するとみられる。

このような自治体では，今後医療，福祉関係の需要 が急増することになるため，デイサービスや特別養護 老人ホームなどの施設の不足が懸念される，また，住 宅地の開発に合わせて整備された水道などのインフラ 
E-journal GEO 2013 Vol. 8(2)

表2『地域別将来推計人口（平成 25 年 3 月推計)』に基づく

「2025年後期高齢者数 / 2010 年後期高齢者数」上位 50 自治体

\begin{tabular}{|c|c|c|c|c|c|c|c|c|}
\hline 都道府県 & 市町村 & $\begin{array}{c}75 \text { 歳以上 } \\
\text { 人口の } \\
2010 \sim 2025 \\
\text { 年の変化 } \\
\text { (倍) }\end{array}$ & 都道府県 & 市町村 & $\begin{array}{c}75 \text { 歳以上 } \\
\text { 人口の } \\
2010 \sim 2025 \\
\text { 年の変化 } \\
\text { (倍) }\end{array}$ & 都道府県 & 市町村 & $\begin{array}{c}75 \text { 歳以上 } \\
\text { 人口の } \\
2010 \sim 2025 \\
\text { 年の変化 } \\
\text { (倍) }\end{array}$ \\
\hline 埼玉県 & 三郷市 & 2.79 & 愛知県 & 大治町 & 2.34 & 埼玉県 & 杉戸町 & 2.23 \\
\hline 埼玉県 & 鶴ケ島市 & 2.76 & 埼玉県 & 春日部市 & 2.31 & 千葉県 & 我孫子市 & 2.23 \\
\hline 埼玉県 & 伊奈町 & 2.71 & 埼玉県 & 三芳町 & 2.31 & 千葉県 & 富里市 & 2.22 \\
\hline 埼玉県 & 吉川市 & 2.64 & 千葉県 & 四街道市 & 2.30 & 埼玉県 & 志木市 & 2.22 \\
\hline 埼玉県 & 八潮市 & 2.59 & 埼玉県 & 日高市 & 2.30 & 埼玉県 & 富士見市 & 2.22 \\
\hline 宮城県 & 富谷町 & 2.57 & 愛知県 & 東郷町 & 2.29 & 茨城県 & 利根町 & 2.22 \\
\hline 千葉県 & 白井市 & 2.54 & 東京都 & 多摩市 & 2.29 & 埼玉県 & 狭山市 & 2.21 \\
\hline 千葉県 & 酒々井町 & 2.46 & 千葉県 & 千葉市 & 2.28 & 埼玉県 & 上尾市 & 2.21 \\
\hline 埼玉県 & 坂戸市 & 2.43 & 大阪府 & 四條畷市 & 2.27 & 愛知県 & 名古屋市 & 2.21 \\
\hline 神奈川県 & 綾瀬市 & 2.43 & 愛知県 & 長久手市 & 2.27 & 茨城県 & 取手市 & 2.21 \\
\hline 茨城県 & 守谷市 & 2.43 & 埼玉県 & 新座市 & 2.26 & 神奈川県 & 相模原市 & 2.20 \\
\hline 茨城県 & 牛久市 & 2.42 & 大阪府 & 枚方市 & 2.26 & 神奈川県 & 愛川町 & 2.20 \\
\hline 愛知県 & みよし市 & 2.42 & 埼玉県 & 北本市 & 2.26 & 千葉県 & 佐倉市 & 2.19 \\
\hline 神奈川県 & 海老名市 & 2.36 & 神奈川県 & 厚木市 & 2.25 & 千葉県 & 松戸市 & 2.19 \\
\hline 埼玉県 & 越谷市 & 2.35 & 埼玉県 & 松伏町 & 2.24 & 大阪府 & 寝屋川市 & 2.18 \\
\hline 千葉県 & 鎌ケ谷市 & 2.35 & 大阪府 & 摂津市 & 2.24 & 京都府 & 八幡市 & 2.18 \\
\hline 埼玉県 & 草加市 & 2.34 & 大阪府 & 豊能町 & 2.24 & & & \\
\hline
\end{tabular}

資料：『日本の地域別将来推計人口（平成 25 年 3 月推計)』(国立社会保障 - 人口問題研究所）より作成.

も，一斉に老朽化を迎えることとなるため，更新等の 手当ての必要が急増する可能性もある.

さらに, 郊外地域特有の問題として, 日常の足の確 保が課題となるだろう。新興住宅地は，駅や既成市街 地から離れていることが多く，また丘陵地にある場合 は地区内の起伏も大きい. 今後自家用車の運転が難し くなる住民の買物等の外出をサポートするために, コ ミュニティバス等の施策をさらに充実させる必要に迫 られるだろう。

その一方, 彼らが現役の頃には比較的潤沢であった 税収も, 退職時期を迎えるとともに落ち込んでいる. したがってこういった自治体では今後財政が非常に厳 しいものとなる可能性が高い. 大都市圈郊外の各自治 体では, 厳しい財政の中, 続出する諸問題にいかに対 応していくか, 難しい舵取りが求められることになる だろう。

\section{4. 大都市圈人口の長期的な人口減少一非大都市圈}

$$
\text { との「タイムラグ」ー }
$$

前節では市区町村単位の推計結果から, 大都市圈郊 外における急激な高齢化を見てきた。 これだけ多くの 市や町で後期高齢者の人口が急増するとなれば, 当然

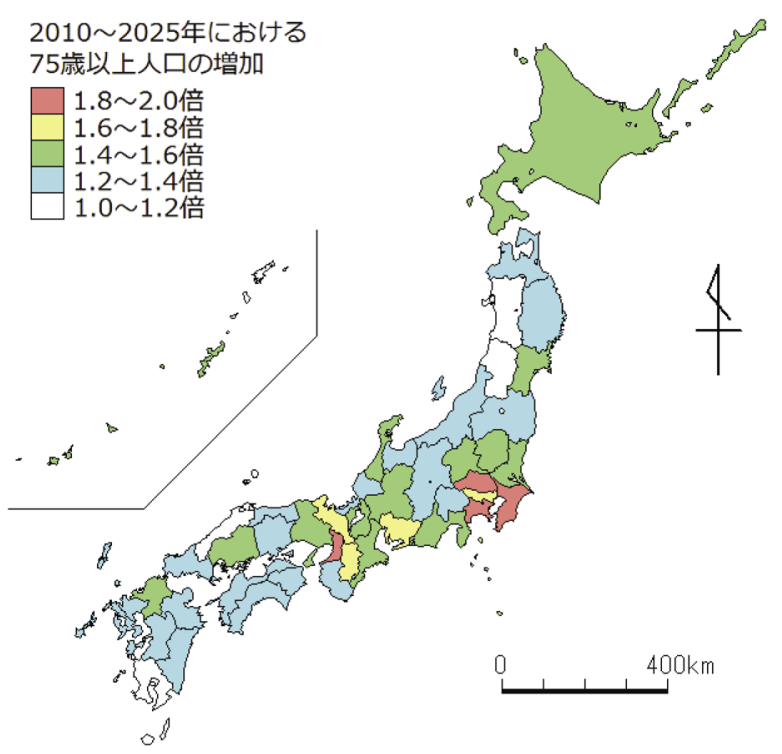

図 7 『地域別将来推計人口（平成 25 年 3 月推計)』に 基づく 2010 ～2025年の後期高齢者の増加 資料：『日本の地域別将来推計人口（平成 25 年 3 月推 計)』（国立社会保障・人口問題研究所）より作成.

県単位でも同様の傾向となることが予想される. 図 7 は, 市区町村別の 75 歳以上人口の推計值を県単位で 集計し，2010年から 2025 年にかけて何倍に増加する かを示したものである. 全都道府県が 1.0 倍から 2.0 倍 


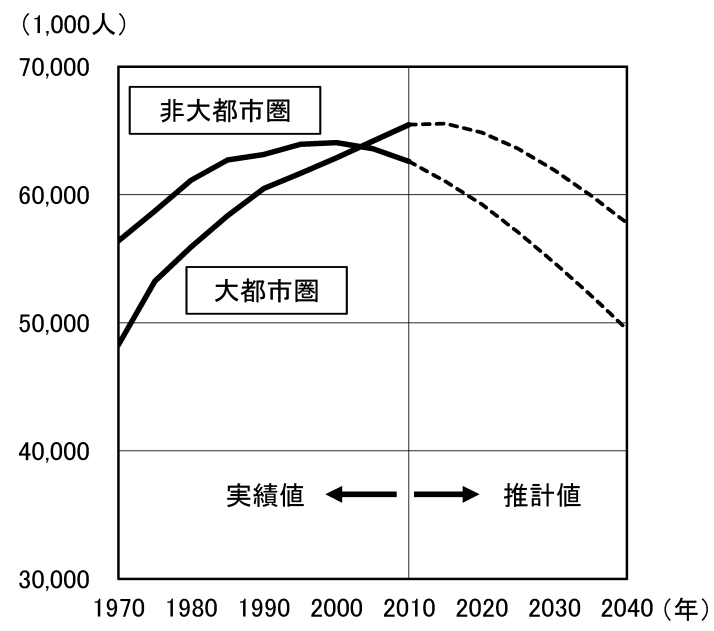

図 8 日本の大都市圈, 非大都市圈の人口変化 注：大都市圈は以下の三大都市圈からなる. 東京大都市圈：埼玉県, 千葉県, 東京都, 神奈川県

名古屋大都市圈：岐阜県, 愛知県, 三重県 大阪大都市圈：京都府，大阪府，兵庫県， 奈良県

非大都市圈は上記以外の道県.

資料：国勢調查，『日本の地域別将来推計人口 (平成 25 年 3 月推計)』(国立社会保障・人口 問題研究所）より作成.

の範囲に収まるが，東京都の周辺3県，すなわち埼玉 県, 千葉県, 神奈川県が揃って最上位の $1.8 \sim 2.0$ 倍 のランクに位置している。 また大阪府が同じ最高ラン クであるほか, 続く $1.6 \sim 1.8$ 倍は東京都, 愛知県, 京都府, 奈良県からなっており，これらのランクが見 事に三大都市圈の各府県によって占められていること が分かる

このように後期高歯者が急増する三大都市圈では, その後必然的に死亡数が増加する. 20 世紀後半以降, これまで大きな人口の増加を経験してきた大都市圈 も，人口減少と無縁ではいられなくなる。推計結果を 都道府県別に集計し，さらに大都市圈と非大都市圈に 分けて合計し，2010年までの実績值とともに見たも のが図 8 である。非大都市圈の人口は 2000 年からすで に減少しており，今後はこれが加速していく，一方の 大都市圈も2015年にはピークに達し，減少局面に入 る。そして次第に減少が加速していくものとみられ る.

地方においても少子化が進んだことなどから，かつ てに比べれば少なくなったものの，非大都市圈から大 都市圈への若年者の移動は続いており, この推計でも
十分そのことは織り込まれている。しかしながら，上 述のように，今後は高度経済成長期に大都市圈に流入 した世代が後期高齢期に入り，徐々に平均寿命に差し かかることから死亡数が高水準となっていくことが避 けられない，また，東京，大阪の両大都市圈では出生 率が低く（例えば，2012年における全国の合計出生

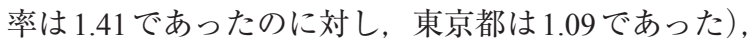
このことも人口減少の要因となる.

今後数十年にわたって人口減少局面の継続が続く日 本にあっては，大都市圈といえども，人口減少からは 逃れられない.もはやこのことを前提としていくこと が重要ではないか. その際の考え方の一つは次のよう なものであろう。日本を大都市圈と非大都市圈に単純 に二分した場合，前世紀後半から今世紀前半にかけて の両者の人口変動の経路は, 本質的には同じであり, タイムラグを有するに過ぎない, というものである. ではその夕イムラグを発生させたものは何か。 それが 本稿でもたびたび言及している，高度経済成長期に発 生した大都市圈への大量の人口移動である.

多くの転出者が見られた時期，非大都市圈では相対 的に若年層が薄く, 高齢層の厚い年齢構造となり, そ の後一足早く人口減少局面に入っていった。一方の大 都市圈では大量の若年者を迎え，当面の高齢化が抑制 された。しかしながらほぼ半世紀が経過した今日，彼 らの加齢は, 大都市圈の年齢構造を高齢層の厚いもの へと急速にシフトさせつつある. 今後は非大都市圈の 後を追う形で死亡数が増え，人口減少へと向かう.

なお，非大都市圈では，かつて大量の若年者を流出 させた分，その後高齢者となるべき層が相対的に薄く なった。図7で見たように，今後の後期高齢者の増加 が，非大都市圈では実はそれほど大きくないのは，こ のことが理由である.

\section{IV おわりに}

以上より，コーホートの考え方を用いた将来人口の 推計が，今後しばらくの見通しとしてはいかに信頼度 の高いものかが理解されたであろう．少なくとも，複 雑さを増す現代社会にあって，人口推計よりも高い精 度で将来の動きを見通せるものは，他にはあまり考え られない. そのことに対する理解も徐々に深まりつつ 
ある。

一例を挙げると, 先日, 日本経済新聞紙上で未来予 測に関する特集記事が揭載された（2013年9月14日 付朝刊別刷 13 面)。それによると，2050年の世界の姿 を予測した報告書をまとめた経団連の担当者は「未来 予測の土台は人口推計である. 人口推計にはあまりブ レがなく，それを基に世界各国の経済規模などをかな り正確に見通せる.」と述べている. 未来予測の中核 に人口推計があることは，こういった業務に携わる 人々の間ではほぼコンセンサスとなっているようであ る.

地域の将来像を考える立場にある地理学界諸兄にお かれても，ぜひ『地域別将来推計人口』の結果に改め てお目通し頂ければと考える。

将来人口推計の描く地域の未来は必ずしも明るいも のではない。しかし，根拠なき楽観論を排し，現実を 直視することによってしか，有効な処方箋を得ること はできないのではないか.

最後に一つ付言しておきたいのは，外国からの移民 についてである。『地域別将来推計人口（平成 25 年 3 月推計)』は, 各市区町村の推計結果の合計が, これ に先立って公表された『日本の将来推計人口（平成 24年 1月推計)』に合うょうに計算されている.この 『日本の将来推計人口』では, 一定数の国外からの転 入が見積もられていることから，『地域別将来推計人 口』ではその転入者が各地域に居住していくことが織 り込まれている。この社人研の全国推計において, 毎 年7万人程度と見積もられている外国人の転入超過 が，大きく変動した場合はどうなるのか，疑問を持た れる向きも少なくないであろう。これは今後の政策に 依存する問題でもあり，先を見通すことは難しい．

ただし，これは筆頭著者の個人的な見解であるが， もし移民の受け入れ基準を緩和したとしても，もはや 人口減少を補うほど大挙して流入してくるという事態
は起こらないのではないかと考えている，それは，移 民の主たる供給元である発展途上国においても，経済 成長や近代化とともに出生率が着実に低下しているた めである。一方で，国連の推計（2012年）において ヨーロッパの約半数の国で $2035 \sim 40$ 年の人口減少が 見込まれているように，ヨーロッパや東アジアに位置 する各国を中心として，多くの先進諸国が日本と同 様，少子高齢化，人口減少局面を順次迎えることにな り，移民の積極的な受け入れを模索する国も増えるだ ろう。少なくなる若年労働力をいかに自国に呼び寄せ るか（あるいは引き止めるか）を，今後各国が競うこ ととなる状況も十分考えられるのである.

\section{文 献}

国立社会保障 - 人口問題研究所 2013。『日本の地域 別将来推計人口一一平成 $22(2010) \sim 52(2040)$ 年平成 25 年 3 月推計 (人口問題研究資料第 330 号)』 国立社会保障・人口問題研究所.

西岡八郎・山内昌和・ 小池司朗 2007a. 地方自治体 に打ける人口および世帯数の将来推計の実施状況と 社人研推計の利用状況——都道府県の場合——人 口問題研究 63(2): 57-66.

西岡八郎・山内昌和・ 小池司朗 $2007 \mathrm{~b}$. 地方自治体 に扔ける人口抢よび世帯数の将来推計の実施状況と 社人研推計の利用状況および人口関連施策への対応 ——市区町村の場合—. 人口問題研究 63(4): 5673.

濱 英彦・山口喜一編著 1997. 『地域人口分析の基 礎』古今書院.

山口喜一編著 1990. 『人口推計入門』古今書院.

Giannakouris, K. 2010. Regional population projections EUROPOP2008: Most EU regions face older population profile in 2030. http://epp.eurostat.ec.europa.eu/cache/ ITY OFFPUB/KS-SF-10-001/EN/KS-SF-10-001-EN. PDF

United States Census Bureau 1996. 1996 state population projections. http://www.census.gov/population/projections/ data/state/stproj1996.html

United States Census Bureau 2005. 2005 interim state population projections. http://www.census.gov/population/ projections/data/state/projectionsagesex.html

\section{〈著者略歴〉}

江崎 雄治（えさき ゆうじ）

専修大学文学部教授. 東京大学大学院理学系研究科博士課程中退. 博士 (理学). 専門は人口地理学.

西岡 八郎（にしおか はち万う）

早稲田大学人間総合研究センター招聘研究員. 早稲田大学大学院文学研究科博士課程単位取得退学. 博士 (人間 科学). 専門は家族社会学・人口学. 


\section{鈴木 透（すずきとおる）}

国立社会保障. 人口問題研究所人口構造研究部長. 北海道大学大学院文学研究科博士課程単位取得退学.

Ph.D. (人口学)。専門は人口学・社会学.

小池 司朗（こいけ しろう）

国立社会保障 - 人口問題研究所人口構造研究部室長. 東京大学大学院総合文化研究科博士課程修了. 博士（学 術). 専門は人口地理学.

山内 昌和 (やまうち まさかず)

国立社会保障 - 人口問題研究所人口構造研究部室長. 東京大学大学院総合文化研究科博士課程修了. 博士（学 術). 専門は人口地理学.

菅 桂太（すがけいた）

国立社会保障 - 人口問題研究所人口構造研究部室長. 慶應義塾大学大学院経済学研究科博士課程単位取得退学. 専門は数理人口学.

貴志 匡博（きし まさひろ）

国立社会保障・人口問題研究所人口構造研究部研究員. 神戸大学大学院経済学研究科博士課程単位取得退学. 専 門は人口地理学. 